\title{
Fundamental Study on Chlorination of Monazite
}

\author{
Isao TAnabe, Shozo TAKase and Hisao Konno \\ Lab. of Azuma Kako \& Co., Ltd., Fushiki-Kushioka, Takaoka, Toyama
}

\section{Preface}

Several reports were presented on direct chlorination of monazite, but details of which were not given of the condition and mechanism. The authors investigated the difference of reactivity of principal components and the conditions of chlorination upon monazite.

\section{Difference of Reactivity of Principal Components}

Theoretical quantity of charcoal was blended with either cerium oxide, lanthanum oxide, thorium oxide or monazite, respectively as shown in Table 1; and then, chlorination was performed under chlorine gas by raising temperature at the rate of $5^{\circ} \mathrm{C} / \mathrm{min}$., and the weight change was traced using thermo balance. Quantity of blended charcoal was calculated by assuming that reaction gas was $\mathrm{CO}$ alone and reaction product of phosphorus was $\mathrm{PCl}_{3}$ alone. The results obtained are shown in Fig. 1 and the results indicate the following facts.

Table 1 Chemical Composition of the Specimens Used in the Experiment (Grain size : 325 mesh)

\begin{tabular}{l|cccccc}
\hline \multicolumn{1}{c|}{ Kind of specimens } & \multicolumn{5}{|c}{ Composition (\%) } \\
\hline Monazite & $\mathrm{R}_{2} \mathrm{O}_{3}$ & 58.1 & $\mathrm{ThO}_{2}$ & 7.97 & $\mathrm{P}_{2} \mathrm{O}_{3}$ & 29.8 \\
& $\mathrm{Fe}_{2} \mathrm{O}_{3}$ & 0.32 & $\mathrm{SiO}_{2}$ & 2.32 & & \\
Cerium oxide & $\mathrm{CeO}_{2}$ & 99.2 & & & & \\
Lanthanum oxide & $\mathrm{La}_{2} \mathrm{O}_{3}$ & 99.5 & & & & \\
Thorium oxide & $\mathrm{ThO}_{2}$ & 98.9 & & & & \\
Charcoal & V.M. & 11.3 & Ash & 2.2 & F.C. & 86.5 \\
Artificial graphite & " & 0.2 & " & 0.1 & " & 99.7 \\
\hline
\end{tabular}

Notes. R: Rare earth, V.M. : Volatile matter, F.C. : Fixed carbon

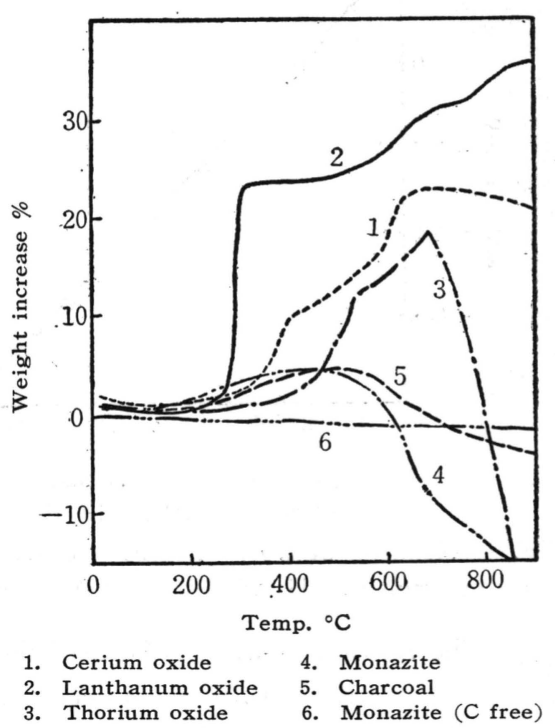

Fig. 1 Thermo-balance curve of chlorination

(1) The reaction of cerium oxide or lanthanum oxid ebegan at $300 \sim 330^{\circ} \mathrm{C}$ or $280 \sim 290^{\circ} \mathrm{C}$, respectively. Secondary abrupt increase of weight was observed at nearly $600^{\circ} \mathrm{C}$ in the both cases.

(2) The reaction of thorium began at about $400^{\circ} \mathrm{C}$, and its extent increased with rising temperature; however, its weight decreased at higher temperature than $690^{\circ} \mathrm{C}$ due to the evaporation of thorium chloride produced.

(3) The reaction of monazite proceeds rather violently above $550^{\circ} \mathrm{C}$, but it is difficult to indicate the biginning temperature of reactions by weight change only, since phosphorus contained may react with chlorine and the products may vaporize. 
However, it is presumed that a part of rare earths changed into oxychloride at $250 \sim 500^{\circ} \mathrm{C}$, considering from the curve of increasing weight of monazite and charcoal,. and composition of reaction products at lower temperature.

(4) When charcoal was heated at $200 \sim 250^{\circ} \mathrm{C}$ in chlorine gas, the weight increase was seen. To clear up this cause, charcoal or graphite was heated up to $450^{\circ} \mathrm{C}$ gradually in chlorine current under the same condition, and weight increase, chlorine content and free chlorine of products were determined. The results are shown in Table 2 . With a artificial a graphite containing no volatile matter very little weight increase was recognized. As a result of this experiment, it is considered that weight increases of charcoal is due to the reaction with chlorine; a part of hydrogen in charcoal was substituted by chlorine.

Table 2 Results Obtained by Heating of Charcoal and Artificial Graphite Powder in Chlorine Gas Using Thermo-balance (Max. temp. $450^{\circ} \mathrm{C}$, rate of temp. rise $5^{\circ} \mathrm{C} / \mathrm{min}$.)

\begin{tabular}{l|c|c|c}
\hline \hline \multicolumn{1}{c|}{ Specimens } & $\begin{array}{c}\text { Rate of weight } \\
\text { increase } \%\end{array}$ & Total Cl\% & Free Cl\% \\
\hline Charcoal powder & 10.3 & 9.4 & $\operatorname{tr}$. \\
Artificial graphite powder & 0.1 & 0.1 & $\operatorname{tr}$. \\
\hline
\end{tabular}

\section{Investigation of Reaction Conditions}

Charcoal was blended with monazite and the mixture was moulded into briquette in size of $4 \sim$ $10 \mathrm{~mm}$ under pressure. Then chlorination was performed by using a quartz-boat in tube furnace to investigate reaction conditions. Scale of the experiment was as large as $20 \mathrm{~g}$ in briquette quantity.

3.1 Effect of reaction temperature Reaction time was fixed at 4 hours. The total quantity of chlorine gas was twice of the theoretical amount and adjusted to pass for $4 \mathrm{hrs}$., and the reaction temperature was investigated. The results obtained are shown in Table 3 and Fig. 2, and the results indicated the following facts.

Table 3 Relation Between the Temperature and the Composition of Reaction Products

\begin{tabular}{|c|c|c|c|c|c|c|c|}
\hline \multirow{2}{*}{$\begin{array}{c}\text { Temp. } \\
{ }^{\circ} \mathrm{C}\end{array}$} & \multicolumn{4}{|c|}{ Composition } & \multicolumn{3}{|c|}{ t. $\%$} \\
\hline & Insol. $\%$ & Insol. $\mathrm{R}$ & Sol. $\mathrm{R}$ & Insol. $\mathrm{Th}$ & Sol. $\mathrm{Th}$ & $\mathbf{P}$ & $\mathrm{C}$ \\
\hline 400 & 97.6 & 37.39 & 0.21 & 5.33 & 0 & 9.87 & 18.2 \\
\hline 450 & 95.6 & 37.32 & 0.58 & 5.30 & 0 & 9.87 & 17.5 \\
\hline 500 & 92.7 & 35.75 & 2.35 & 5.43 & 0 & 10.04 & 13.0 \\
\hline 550 & 60.3 & 33.55 & 16.45 & 5.15 & 0.35 & 3.90 & 11.0 \\
\hline 600 & 29.8 & 5.2 & 35.7 & 4.15 & 1.56 & 2.44 & 7.5 \\
\hline 650 & 17.5 & 0.7 & 41.0 & 2.89 & 2.01 & 0.675 & 7.4 \\
\hline 700 & 9.19 & 0.2 & 43.6 & 1.70 & 2.52 & 0.042 & 6.9 \\
\hline 750 & 6.83 & 0.1 & 45.7 & 0.97 & 2.98 & 0.039 & 5.0 \\
\hline 800 & 5.50 & 0 & 47.8 & 0.14 & 3.55 & 0.035 & 3.9 \\
\hline 850 & 5.00 & 0 & 50.3 & 0.01 & 2.71 & 0.195 & 1.5 \\
\hline 900 & 3.80 & 0.1 & 52.7 & 0 & 1.30 & 0.659 & 0.16 \\
\hline 950 & 8.75 & 3.1 & 50.1 & 0.10 & 0.64 & 1.13 & 0.12 \\
\hline 1000 & 22.3 & 11.3 & 42.4 & 0.01 & 0.19 & 2.00 & 0.10 \\
\hline
\end{tabular}

Reaction $4 \mathrm{hrs}$.

(1) Chlorination of rare earths and phosphorus in monazite proceeded considerably at $550^{\circ} \mathrm{C}$, and the reaction rate increased with rising temperature and reached the maximum at $700 \sim 850^{\circ} \mathrm{C}$, but it decreased above $850^{\circ} \mathrm{C}$ which is the melting point of the reaction products. At higher temperature evaporation loss of rare earths was rather large.

(2) Reaction of thorium in monazite proceeded at higher temperature than that of rare earths or of phosphorus, and the reaction rate was almost the maximum at $800^{\circ} \mathrm{C}$. Its reaction rate did not decrease at higher temperature such as $950 \sim 1000^{\circ} \mathrm{C}$, and the separation was almost complete by evaporation. 


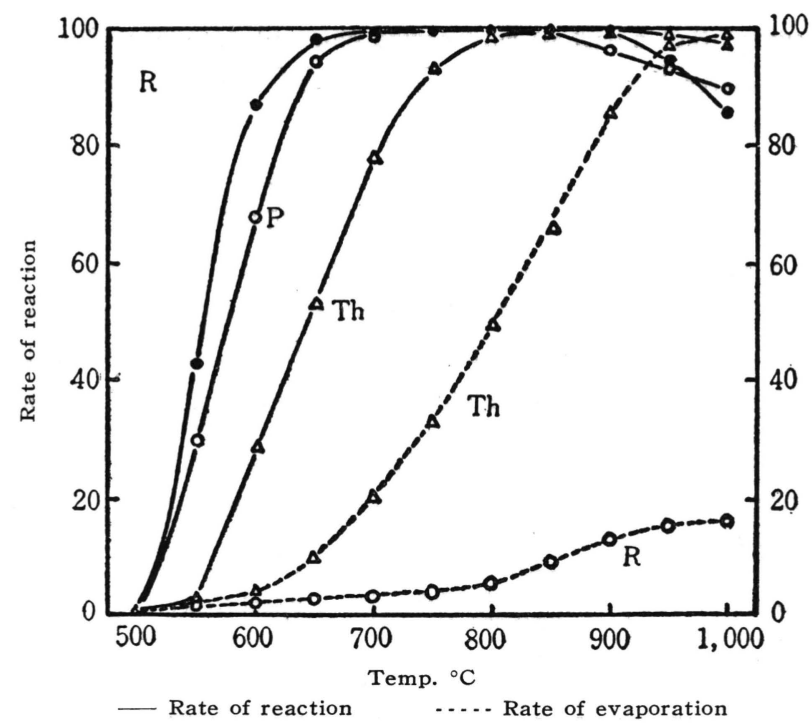

Fig. 2 Relation among temperature and rates of reaction, and of evaporation of thoria and rare earth

3.2 Composition of products at low temperature Cerium oxde, lanthanum oxide or monazite were chlorinated. at low temperatures such as $400 \sim 450^{\circ} \mathrm{C}$, and the existence of their oxychlorides in intermediate products were investigated. The results obtained are shown in Table 4 . Waterinsoluble chlorides caused by the formation of oxychlorides was identified in the reaction products of cerium oxide at $400^{\circ} \mathrm{C}$ and monazite at $400^{\circ} \mathrm{C}$, but not observed in the reaction product of lanthanum oxide at $400^{\circ} \mathrm{C}$.

Table 4 Composition of Reaction Products at Temperature

\begin{tabular}{|c|c|c|c|c|c|c|}
\hline \multirow{2}{*}{$\underset{ }{\text { Temp. }}$. } & \multicolumn{3}{|c|}{ Composition } & \multicolumn{2}{|l|}{ t. $\%$} & \multirow{2}{*}{ Charge and mixing ratio } \\
\hline & Insol. & Insol. $\mathrm{R}$ & Sol. $\mathrm{R}$ & Insol. $\mathrm{Cl}$ & Sol. Cl & \\
\hline 400 & 90.3 & 42.6 & 5.10 & 5.34 & 3.77 & $\mathrm{CeO}_{2}$ : Charcoal \\
\hline 450 & 59.5 & 20.5 & 22.9 & 2.43 & 17.47 & $86.1: 13.9$ \\
\hline 400 & 97.6 & 37.39 & 0.21 & 8.22 & 1.53 & Monazite : Charcoal \\
\hline 450 & 95.6 & 37.32 & 0.58 & 9.26 & 2.00 & $80.6: 19.4$ \\
\hline 400 & 32.4 & 16.7 & 37.4 & 0 & 28.3 & $\begin{array}{c}\mathrm{La}_{2} \mathrm{O}_{3}: \text { Charcoal } \\
88.5: 11.5\end{array}$ \\
\hline
\end{tabular}

Reaction time : 4 hrs.

3.3 Effect of reaction time Temperature of chlorination upon monazite is classified into two groups; one is the temperature above the melting point of the product and the other is that below the melting point. Therefore, reaction time was investigated at $900^{\circ} \mathrm{C}$ and $700^{\circ} \mathrm{C}$. The results obtained are shown in Table 5 and the following facts were classified.

Table 5 Relation Between Time and Reaction Rate

\begin{tabular}{|c|c|c|c|c|c|c|}
\hline \multirow{2}{*}{$\begin{array}{c}\text { Temp. } \\
{ }^{\circ} \mathrm{C}\end{array}$} & \multirow{2}{*}{$\begin{array}{l}\text { Time } \\
\text { hrs. }\end{array}$} & \multicolumn{2}{|c|}{$\mathrm{R}$} & \multicolumn{2}{|c|}{ Th } & \multirow{2}{*}{$\begin{array}{c}\mathrm{P} \\
\text { Rate of } \\
\text { reaction \% }\end{array}$} \\
\hline & & $\begin{array}{l}\text { Rate of } \\
\text { reaction \% }\end{array}$ & $\begin{array}{c}\text { Rate of } \\
\text { evaporation } \\
\%\end{array}$ & $\begin{array}{l}\text { Rate of } \\
\text { reaction \% }\end{array}$ & $\begin{array}{c}\text { Rate of } \\
\text { evaporation } \\
\%\end{array}$ & \\
\hline 700 & 1 & 91.0 & 3.4 & 28.5 & 3.1 & 78.1 \\
\hline$"$ & 2 & 94.6 & 2.0 & 60.1 & 18.3 & 85.1 \\
\hline$"$ & 4 & 99.5 & 3.5 & 78.4 & 20.5 & 99.6 \\
\hline 900 & $1 / 2$ & 72.1 & 11.0 & 55.7 & 48.9 & 71.9 \\
\hline$"$ & 1 & 77.6 & 16.1 & 72.4 & 68.8 & 82.2 \\
\hline " & 2 & 97.9 & 10.2 & 94.8 & 83.7 & 95.5 \\
\hline$"$ & 4 & 99.9 & 12.5 & 100.0 & 85.8 & 95.8 \\
\hline
\end{tabular}


(1) The reaction rates of rare earths and phosphorus were sufficiently high at $700^{\circ} \mathrm{C}$ for $4 \mathrm{hrs}$., while that of thoria was rather low.

(2) At $900^{\circ} \mathrm{C}$, reaction rate of thoria was high, but the evaporation loss of rare earths was also high.

3.4 Composition of gas produced Gas produced by the reaction was gathered and the ratio of $\mathrm{CO}_{2}$ to $\mathrm{CO}$ was investigated. The result obtained is shown in Fig. 3. The content of $\mathrm{CO}_{2}$ was high in the product at low temperature, and it increased with proceeding reaction.

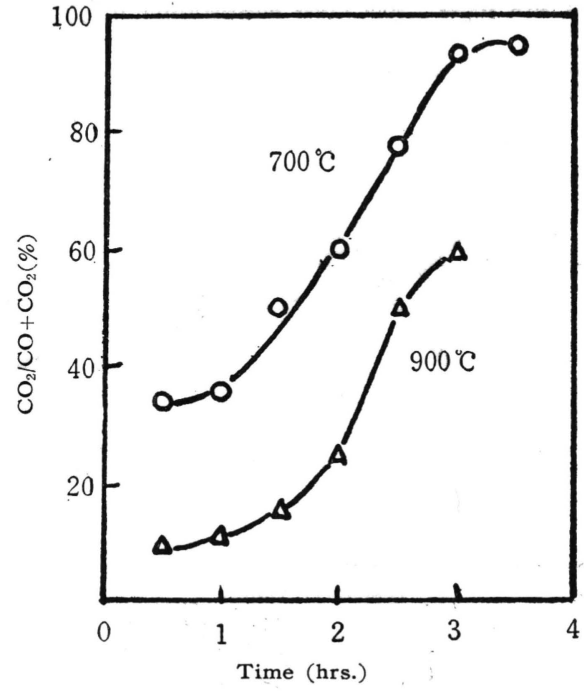

Fig. 3 Relation between time and gas composition

\subsection{Composition of phosphorus chloride}

Briquettes were directly set in a porcelain tube, and chlorination was performed on the scale of $200 \mathrm{~g}$ briquettes; then distilled phosphorus chlorides were gatheredfor fractional distillation. The results obtained by fractional distillation are shown in Table 6 , and the results identified that phosphorus oxychloride was principal component and trichloride by-product.

Table 6 Result of Fractional Distillation of Condensate

\begin{tabular}{|c|c|c|c|c|}
\hline \multicolumn{2}{|c|}{ Time hrs. } & 5 & 5 & 8 \\
\hline \multicolumn{2}{|c|}{$\begin{array}{l}\text { Rate of } \mathrm{Cl}_{2} \text { volume per } \\
\text { theoretical volume : } \%\end{array}$} & 91.2 & 91.2 & 172.0 \\
\hline \multicolumn{2}{|c|}{$\mathrm{P}$ content of reaction product $\%$} & 1.90 & 1.97 & 0.25 \\
\hline \multicolumn{2}{|c|}{ Rate of reaction of $\mathrm{P} \%$} & 83.5 & 83.2 & 98.9 \\
\hline \multicolumn{2}{|l|}{ Yield of distillate } & 56.0 & 50.0 & 74.7 \\
\hline \multirow{3}{*}{$\begin{array}{c}\text { Yield of fraction } \\
\%\end{array}$} & $\sim 102^{\circ} \mathrm{C}$ & 15.4 & 10.1 & 11.9 \\
\hline & $102 \sim 107^{\circ} \mathrm{C}$ & 70.4 & 78.4 & 52.5 \\
\hline & residue & 14.2 & 11.5 & 35.6 \\
\hline
\end{tabular}

3.6 Effect of addition ratio of carbon Briquettes were made with several addition ratios of charcoal, and chlorination was performed at certain temperature below or above the melting point of the reaction products. The result obtained are shown in Table 7 and the results indicated that the addition ratio should be less than that of theoretical value below the melting point and be more than that of theoretical value at higher temperature than the melting point of the product.

Table 7 Relation Between Carbon Ratio and Reaction Rate

\begin{tabular}{|c|c|c|c|c|c|c|}
\hline \multirow{2}{*}{$\begin{array}{l}\text { Temp. } \\
{ }^{\circ} \mathrm{C}\end{array}$} & \multirow{2}{*}{$\begin{array}{c}\text { Carbon ratio } \\
\%\end{array}$} & \multicolumn{2}{|c|}{$\mathrm{R}$} & \multicolumn{2}{|c|}{$\mathrm{Th}$} & \multirow{2}{*}{$\begin{array}{c}\mathrm{P} \\
\text { Rate of } \\
\text { reaction \% }\end{array}$} \\
\hline & & $\begin{array}{l}\text { Rate of } \\
\text { reaction \% }\end{array}$ & $\begin{array}{c}\text { Rate of } \\
\text { evaporation } \\
\%\end{array}$ & $\begin{array}{l}\text { Rate of } \\
\text { reaction \% }\end{array}$ & $\begin{array}{c}\text { Rate of } \\
\text { evaporation } \\
\%\end{array}$ & \\
\hline 750 & 100 & 99.7 & 3.8 & 93.0 & 33.2 & 99.7 \\
\hline " & 90 & 99.8 & 3.1 & 92.8 & 33.5 & 99.7 \\
\hline$"$ & 85 & 99.2 & 3.3 & 92.2 & 34.3 & 99.7 \\
\hline$"$ & 80 & 98.5 & 2.9 & 92.0 & 35.2 & 99.5 \\
\hline$"$ & 75 & 95.5 & 2.5 & 92.5 & 35.7 & 98.3 \\
\hline 1000 & 110 & 90.5 & 13.7 & 100.0 & 100.0 & 88.9 \\
\hline " & 100 & 85.5 & 15.5 & 97.2 & 98.5 & 88.0 \\
\hline " & 90 & 64.0 & 15.8 & 91.5 & 98.3 & 81.0 \\
\hline
\end{tabular}

Reaction time : 4 hrs.

(Received Apr. 14, 1960)

\section{Literature :}

1) F.R. Hartley, A.W. Wylie, J. Soc. Chem. Ind. 69, 1 (1950).

2) F.R. Hartley, A.W. Wylie, J. Appl. Chem. 2, 24, (1952). 